\title{
Disclosure Level and Compliance with IFRS: An Investigation of Ghanaian Firms
}

\author{
Abdul Mansulu \\ Faculty of Business and Economics, Mendel University in Brno, Zemedelska 1/1665, 61300, Brno, Czech \\ Republic
}

\begin{abstract}
IFRS is a timely response to the globalization of business activities in the area of financial reporting practice. This study empirically examines the extent of compliance of Ghanaian listed firms with IFRS disclosure requirements. It secondly identifies the firm-specific factors stated as company size, profitability, leverage, auditor type, company age, and the type of industry that influence the variation in the level of compliance. The study uses a longitudinal dataset of 2008 to 2017 annual reports of 35 listed firms. The study adopts both the dichotomous approach (DA) and partial compliance approach (PA) of measuring compliance in other to make an informative outcome. The findings reveal an average compliance score of $86.4 \%$ (DA) and $85.8 \%$ (PA). On records, there is still significant non-compliance with IFRS mandatory disclosure. When the corporate attributes are regressed, the study shows that larger firms and firms audited by the BIG 4 accounting firms have a significant positive association with the level of compliance. Profitability shows a significant negative association also under both compliance measures. On the flip side, there is no statistical significance identified for leverage and company age. To test the sensitivity of the regression analysis, a robustness test is conducted and the outcome rarely differs. The study is essential as investors' decisions lean on this knowledge and also, this study is the first of its kind to use both compliance methods side by side.
\end{abstract}

Keywords: International Financial Reporting Standards, corporate disclosure, listed firms, Ghana.

DOI: $10.7176 /$ RJFA/12-23-04

Publication date: December $31^{\text {st }} 2021$

\section{Introduction}

IFRS is a remarkable height in the history of accounting. It has facilitated a better understanding of financial reporting by investors and other stakeholders worldwide due to the uniformity in presenting and preparing financial reports. It also brings dynamism to the discussion of access to funds in the capital market. Over 150 countries (across Europe, the Americas, Asia, the middle east, and Africa) have adopted IFRS as the required standard for financial reporting. It is close to 5 decades since the issuance of IAS/IFRS, but many countries have instead adopted IFRS in the recent two decades. Subsequently, the far-reaching benefits and challenges have been analyzed through the lens of IFRS literature for the net gain. It is argued that IFRS offers more benefits than National GAAP in terms of transparency and comparability, increases market efficiency, and decreases capital cost (Brown, 2011). Before adopting IFRS, the preparation and presentation of the financial statement were more localized by using the country-specific accounting standards (GAAP). However, over time businesses have grown and expanded beyond borders. For a financial report to hold understanding across a broader spectrum of readership, the accounting system peculiarities of countries reasonably were to be dealt with (Yiadom and Atsunyo, 2014). The challenge of having a set of financial statements which communicate a uniform meaning and appeals intellectually, whether local or international, was inevitable. Therefore, a consistent collection of quality financial information became necessary since non-understandable financial details added to the cost of capital and lack of investor confidence for such reasons could account for the loss of investment opportunities.

Flynn (2008) suggested that critically having a common way of reporting was imperative. International Accounting Standard Committee (IASC), in the year 1973, initiated the idea of harmonizing financial reporting standards. IASC was formed by ten developed countries to provide basic standards purposely aimed to aid a single approach to report financial statements and being the overbearing light to which all annual reports preparation can be benchmarked (Zeff, 2012). The IASC, which initially issued IAS, was replaced by the International Accounting Standard Board (IASB) in 2001, which for more than two decades has the mandate to issue IFRS (IAS Plus, 2021). The term IFRS refers to the entire IASB standards and includes the old IAS and IFRS interpretation (IAS Plus, 2021). Over the past decades, many countries have adopted IFRS to improve quality reporting as a framework for financial reporting.

In 2007, Ghana saw fit upon coming to terms with the conspicuous need for access to the capital market and subsequent promotion of economic growth to adopt IFRS. Ghana entirely ceased using its local GAAP (known as Ghana National Accounting Standards) and adopted IFRS fully to pursue this trajectory within the financial reporting space. However, this was for only listed companies, banks, utility organizations, and government agencies who were mandated to implement the standards close to the 2008 financial year. This study investigates 
the level of compliance of Ghanaian listed companies with IFRS required disclosure and the corporate attributes that drive variation in compliance. Several empirical studies conducted on this topic in developed countries (Glaum and Street, 2003; Street and Gray, 2002) and in developing countries like (Al-Shammari, 2011, Yiadom and Atsunyo, 2014) have outcomes inconsistent with the claim by auditors that the annual reports of companies they audit are fully compliant to IFRS. Earlier studies have used a single firm or a standard or multiple standards or years less than a decade in Ghana. However, this study is far-reaching since it uses ten-year longitudinal panel data to analyze and reach an outcome comprehensively. With scant work done in developing countries, this study adds to the IFRS literature on compliance disclosure.

Additionally, little work globally has been done using both methods of the unweighted approach in measuring compliance and this is the first time in the Ghanaian context. This research facilitates better disclosure practices in Ghana as firms' compliance is revealed and room for improvement made available. The rest of the study has the following organization. Section two focuses on the literature and the hypothesis development, which explains the empirical and theoretical literature. The remaining sections focus on the methodology, results of discussion and summary, conclusion, and recommendation of the study in sections 3,4 , and 5, respectively.

\section{Literature Review}

\subsection{The financial Reporting Environment in Ghana}

Several factors influence the financial reporting regime in a particular country. Assenso-Okofo et al. (2011) pointed out legislation, economic, political, international relations as the factors, especially in the Ghanaian environment. Al-Shammari (2011) added culture as a factor in his studies. Choi and Muelles (1992) again added that the education system also influences accounting practices. These external factors form the bedrock on which the framework of financial reporting practices anchor. The Institute of Chartered Accountants Ghana (ICAG) is the central pillar for formal accounting in Ghana. It is an educational element among the environmental actors whose responsibility is to ensure formal training of accountants and auditors who are magnanimous actors in the sustainability of financial reporting.

The Companies code of 1963 (Act 179), now replaced by the companies Act 2019 (Act 1992), guides the reporting of Ghana in terms of legislation. Subsumed in the Act are the details that interrogate the operations, establishment, and provisions of winding up of companies. The legislation document enjoins preparers of financial statements to report statements that comply with the adopted IFRS. Precedent to the use of IFRS was the Ghana National Accounting Standards (GNAS), which comprised 28 standards that were country-specific but were outdated and replaced by IFRS. In Ghana, the Ghana Stock Exchange (GSE) as a regulator operates within a set of rules enshrined in the GSE rule book, which expresses membership operations and other regulatory requirements. The listed companies, requirements for listing and accounting provisions are documented in the securities and exchange rules with enforcement expected from the stock exchange and the Securities and Exchange Commission (SEC). The GSE, in harmony with the SEC of Ghana, requires all listed organizations to abide by their guidelines of compliance with the applicable financial reporting standards. Notwithstanding the expectations, it was opined by Assenso-Okofo (2011) that the reporting system is neither effective nor efficient due to the frail monitoring and enforcement of compliance. In recent years, the GSE has gained recognition and chalked some laurels that can't be overlooked. The GSE's better management, grounded in its remarkable achievement and enviable record in 2017, gave it a widespread appeal to indigenous and exotic investors. The achievement positioned Ghana to gain international recognition in the capital market and made it possible to compete for capital allocation in the global funds market. The GSE received the rating as the best performing among the African markets, with a 58\% gain in performance in the 2009 financial year (GSE, 2009). In terms of market capitalization, the value tripled from 2010 to 2014 from GHC20116.70 million to GhC64352.40 million. The results came about due to new listings (e.g. Tullow Oil Plc) in 2011 (GSE, 2009). The tremendous growth of the flow of capital by firms on the stock exchange is inextricable from commitment to transparency by firms that have agreed to report their financial statement as a critical requirement for listing.

\subsection{Empirical Review}

Studies on compliance with IFRS have gained widespread attention as it is progressive and again depicts gradual changes in issuing new standards. Since its implementation, studies conducted have shown significant noncompliance with IFRS as documented (Glaum and Street, 2003; Street and Gray, 2002 and Cairns, 2001). These documented studies found challenges in compliance with most IFRS standard parameters (Glaum and Street, 2003; Street and Gray, 2002). Empirical studies conducted by Street et al. (1999) performed a survey of ten standards (IAS 2, IAS 8, IAS 9, IAS 16, IAS 18, IAS 19, IAS 21, IAS 22, IAS 23, and IAS 29), and there was evidence of a lower level of compliance. In the study, a total of 49 firms were extracted from 12 countries.

In other studies, a larger dataset of 279 firms from 32 countries showed indifferent results from the earlier studies. Other standards different from the enlisted standards in Street et al. (1999), like IAS 12, IAS 14, IAS 32, and IAS 33, showed poor compliance scores (Street and Gray, 2002). The study again concluded that compliance 
is country-based and provided evidence of variation as Chinese companies were more compliant than firms in France

Rajhi (2014), on the score of two measuring approaches, conducted a study in France using 118 firms listed on the New York Stock Exchange (NYSE) Euronext post-2005 for the years 2009 and 2010. The study summarized that non-compliance with IFRS mandatory disclosure was the general findings. The study used ten standards parameters. The recorded mean compliance score was $70.37 \%$ and $72.5 \%$ for the dichotomous and partial compliance methods. Consequently, the researcher argued that the differences could be attributed to a margin of error to the dichotomous approach due to the variation in the number of items for the individual standards.

Al-Shammari et al. (2008) examined the level of compliance with IFRS in six Gulf Co-operation Council (GCC) countries, namely Bahrain, Kuwait, Saudi Arabia, United Arab Emirates (UAE), Oman, Qatar from 1996 to 2002. They argued that compliance score was high (above 80\%) for seven standards (IAS 1, 16, 18, 23, 24, 27, and 30). Also, the compliance score was in variance among the countries. Critical factors as assigned were due to the factors such as the institutional framework of a country, enforcement mechanism, regulations, even with a close culture and similarity in terms of economy, apparent differences in compliance shows (Abdullah et al., 2012). There wasn't full compliance over the period, but the study assumed a progressive trend in compliance.

In terms of the corporate attributes, Appiah et al. (2016), a typical paper in a similar study, revealed a significant positive association between compliance and firm size, auditor type, cross-listing, and industry sectors (IT and Agro-processing). On the contrary, the company age, leverage, and profitability had no such association.

Zakari (2014) lamented that the variability to achieve full compliance has to do with the unfamiliarity of the new standards. He argued that adoption and implementation through training are costly relative to the firm's size. Such cost aspect causes smaller firms to settle for not-too-professional accountants who consequently prepare financial statements lacking full compliance.

Adducing other arguments, Chatham (2008), in an earlier study, postulated that a firm's attestation regarding their use of IAS in the financial statement was enough to conclude that the firms are complying with the International Accounting Standard Committee (IASC)/ International Accounting Standard Board (IASB). For instance, sheer observation of the financial statement report attestation by auditors in Ghana will make one believe that the financial statement of the listed firms was fully compliant since auditors gave assurance that financial statements conform to IFRS.

Ashbaugh and Pincus (2001) in the line of the impact study, assessed the accuracy of forecast earnings by analyst ability by investigating the impact of IAS. The study findings were that the value of analyst forecast error is analyzed as the analyst's ability to forecast earnings improves through the adoption of IAS.

\subsection{Hypothesis Development and Theory}

There are several underlying theories on which most management concepts are grounded. In the area of IFRS compliance disclosure requirements, the agency theory is dominant in the literature on IFRS compliance disclosure (Hossain et al. 1995). The agency problem is assumed to exist between managers and shareholders as their interest conflicts. This conflict is not a phenomenon in a category of the economy but protruded in developing economies. The lack of a robust legal framework or system, information asymmetry, and weak capital markets characterize the agency problem's extent. With the agency cost in place, Jensen and Meckling (1976) submitted three cost constituents: bonding cost, monitoring cost, and residual loss. According to management scholars, increased compliance with IFRS disclosure requirements indicates improvement in transparency and disclosure. Jallad (2020) emphasized that a manager's commitment to disclose financial information reduces information asymmetry between the principal and the agents (managers) and agency costs. Incurring the agency cost is an indication to reduce the agency problem, and that expression can be exemplified by complying with IFRS mandatory disclosure.

Capital needs management scholars also suggest this theory to explain financial information disclosure. Earlier studies have hypothesized a relationship between the cost of capital and financial disclosure where the cost of capital reduces as disclosure is made as investor's uncertainty also reduces. It denotes a way for firms to raise money at a reduced price of capital and in return, provide more disclosed information to curtail information asymmetry (Samaha and Khlif, 2016). The theory expects firms to be willing to comply with the IFRS disclosure requirement through increased disclosure to gain financial market benefits. Several empirical evidence is provided at varying levels of IAS/IFRS compliance across firms, countries, and regions on the premises of the explained ideas. The many corporate factors have occasioned such differences in the compliance based on IFRS literature.

Extant studies have found significant variation in compliance with IFRS with several factors accused of such differences ranging from corporate governance, firm-specific factors, cultural factors, among others. Such factors influence the level of compliance. For this reason, the study develops six firm-specific characteristics to 
know the extent of the listed firms in the Ghana Stock Exchange. The reason for choosing these characteristics is that they significantly influence the level of accounting standard disclosure compliance per prior standards.

2.3.1 Company Size

There are mixed results on the relationship between the company size and the level of compliance. Studies including Ali et al. (2004), Ibrahim (2006), Fekete et al. (2008), Palmer (2013), and Juhmani (2012) found a significant connection between the size of the company and the level of compliance disclosure. In line with the capital needs theory, more prominent firms' ability to raise capital at a lower cost is due to such compliance. Several others have argued that larger firms can disclose more information since the direct price required to make such disclosures by collecting, processing, and publishing are relatively affordable for larger firms, unlike smaller firms. Patton and Zalenka (1997), Glaum and Street (2003), and Demir and Bahadir (2014) fail to discover a correlation between the firm size and the level of compliance. In the empirical literature, the agency theory also supports the belief that large firms comply with IFRS disclosure and based on that, the study hypothesizes that:

H1: There is a significant positive relationship between company size and the extent of IFRS mandatory disclosure requirements.

2.3.2 Profitability

Several disclosure studies have predicted a positive relationship between profitability and mandatory disclosure with IFRS. To confirm it, prior studies (Agyei-Mensah, 2014; Ali et al., 2004) reported that profitability is related to the IFRS mandatory disclosure requirement. In contrast Alsaeed (2006), Juhmani (2012), Appiah et al. (2016), Galani et al. (2011), Demir and Bahadir (2014) and Al-Mutawaa and Hewaidy (2010) noted no such relationship. An argument for the positive relationship Meek et al. (1995) argued that with public trust won, performing firms are motivated to disclose enough information. Concerning the above studies, the study hypothesizes that:

H2: Profitable firms have significant positive association with the level of compliance with IFRS mandatory disclosure requirements

2.3.3 Leverage

Leverage has gained attention as a firm-specific attribute relevant to influence the variation in the level of compliance. Jensen and Meckling (1976) argued that a firm's leverage grows with increases with the level of compliance with financial information disclosure. Al-Shammari (2011) indicated that it is assuring that higher leverage firms note that they expect to reduce agency costs by complying with IFRS to reassure debtholders that their interest is covered. An investigation into the shareholders-debtholders discussion on IFRS compliance literature exhibits an achievement of mixed results. The results of studies by Jaggi and Low (2000), AlShammari (2008), Ali et al. (2004), and Ahmed and Nicholls (1994) confirm the belief that leverage responds positively to the increase in the extent of mandatory disclosure with IFRS. On voluntary studies, Patelli and Prencipe (2007), Samaha et al. (2012) also found positive relation. Elfeky and Nasiri (2017) and Eng and Mak (2003) believed in the hypothesis of a positive relationship between leverage and the level of mandatory disclosure yet achieved a contradictory result (that is, negative association). Firms with higher obligations payable as a justification to meet the requirement of their debtholders will provide enormous financial data than firms with a low debt obligation. From the above argument, the study hypothesizes that:

H3: Leverage has significant positive association with the IFRS mandatory disclosure requirement.

\subsubsection{Auditor Type}

The auditor type is a famous variable in empirical literature as a firm attribute that influences compliance. Demir and Bahadir (2014) revealed that firms audited by BIG 4 have a positive correlation with compliance. In the lens of the agency theory, DeAngelo (1981) posits that a firm that engages the BIG 4 set to minimize the agency cost. The knowledge of such experiences and adept professionals for audit purposes causes managers to disclose more as they also dispel the motive to withhold crucial information. Demir and Bahadir (2014), Glaum and Street (2003), Appiah et al. (2016) all reported a positive association between the two variables. In contrast, studies by Al-Mutawaa and Hewaidy (2010) found no such evidence. From the above, the study hypothesizes that:

H4: The type of audit firm that audit the company's financial statement has a significant positive relationship with the level of compliance with IFRS mandatory disclosure requirements.

\subsubsection{Company Age}

There are varying results on the age of firms in line with it influencing the level of compliance. In an extant study, Glaum and Street (2003) predicted a positive relationship between age and compliance. Older firms have existed for long years in the business space, and exposure and familiarity in the business environment and the signal of growth and reputation protection propels compliance with mandatory disclosure more likely. Alsaeed (2006) and Juhmani (2012) found no such association. Some arguments stand that the length of existence gives most older firms the ability to be resourceful to hire professionals and personnel capable of reporting financial statements following IFRS requirements. Young firms are likely not to disclose more information due to the proprietary cost of making sensitive public information known to established competitors (Owusu-Ansah, 1998). 
Several studies on the empirical literature have investigated the effects of company age on mandatory disclosure. Al-Shammari (2011) and Hossain and Hammani (2019) found that the degree of compulsory disclosure is an increasing function of company age. Glaum and Street (2003), Juhmani (2012), Alsaeed (2006) found no such association between the two variables. The study hypothesizes that:

H5: There is a significant positive relationship between the company age and the extent of IFRS mandatory disclosure requirements.

2.3.6 Industry Type

Empirical studies suggest variation in the degree of compliance with IFRS disclosure requirements for the various industries (Owusu Ansah, 1998). A particular standard may have mixed applicability for diverse industries. For instance, IFRS 6 may apply only to the mining and oil industry but not to pharmaceutical and beverage. One standard may also not be commonly use among some sectors. For instance, IAS 2 inventory is a common standard used by manufacturing industries unlike the financial industries. In empirical studies, Street and Bryant (2000) found no such association between the level of compliance and the industry type but Street and Gray (2001) found a positive association in the case of voluntary disclosure and a firm being in the commerce and transportation industry. Tower et al. (1999) and Al-Shammari (2005) also recorded a positive relationship between the level of compliance and the industry type. The study therefore hypothesized that:

H6: There is variation in the industry type and the level of compliance with IFRS mandatory disclosure requirements.

\section{Methods}

\subsection{Sample Data}

This study adopts the qualitative research design approach to assess how the firms listed on the GSE have complied since implementation of IFRS. A total of 44 firms were listed on the GSE but sampled for 35 firms. The exclusion of firms is on the grounds of unavailable data, incorporation outside Ghana and using non-IFRS as the basis for reporting. The sample firms comprise 35 firms categorize into industries as financial (11), manufacturing/trading (7), agro/processing (4), mining/oil (4), pharmaceutical/beverage (4), and paper converter/IT/services (5). This study covers 10-year post-adoption, that is, 2008-2017. In all, the study comprises 288 firm-year datasets.

\subsection{Data Collection}

The study obtains data from secondary sources. The sources include the GSE website, the company's website and a few from the African market portal. The data for the dependent and independent variables are extracted from the annual reports of the chosen firms. Other details like the company age are obtained from the GSE fact book, which highlights the year of incorporation and listing of all companies.

\subsection{The Scoring Method and Disclosure Checklist}

A self-constructed disclosure checklist is developed to measure the extent of compliance with IFRS disclosure requirements. The self-constructed approach is consistent with prior studies on mandatory disclosure (Ali et al., 2004; Glaum and Street, 2003; Owusu-Ansah, 1998). With evidence from extant work, there are two popular measurement approaches to determine the extent of compliance with the IFRS disclosure requirement: weighted and unweighted disclosure indices. (Cooke, 1989). Glaum and Street (2003) and Street and Bryant (2000) emphasized that the most common is the unweighted disclosure index. The unweighted disclosure index has an advantage especially when no particular user groups are involved. This allows some independent analysis. The disclosure items are treated with equal weight as repeated in several studies (Owusu-Ansah and Yeoh, 2005; Ali et al., 2004; Street and Bryant, 2000). The unweighted approach has two sub-measures: the dichotomous and partial compliance (PC) methods, with the former being widely used (Glaum and Street, 2003; Demir and Bahadir, 2004).

Notwithstanding the widespread use of the dichotomous approach, Al-Shiab (2003) argued that it has its frail because the equal weight assigned for each item might give priority to standards with many disclosure items compared to standards with fewer disclosure items. The alternative approach is the partial method, which gives equal weight to the standards (Al-Shiab, 2003). Both ways have a converging path based on the assumption that all disclosure items are equally important to all user groups. The contrast lies in the computation of the compliance index.

Tsalavoutas et al. (2010) conducted a study on measuring the disclosure compliance index using both suggested methods to identify variation in compliance scores for the two approaches to examine their outcome. Empirical studies have consistently shown variations in the compliance index with support in favor of the dichotomous approach (Tsalavoutas and Evans, 2010; Abdullah and Minhat, 2013). In the Ghanaian context, researchers have used both methods separately in several studies. Appiah et al. (2016) used the partial method and the dichotomous method was used in other studies (Yiadom and Atsunyo, 2014; Appiah-Kubi and Rjoub, 
2017). For deepening the outcome, this study uses both methods simultaneously to reach an informative outcome. On the standards, 24 standards are employed for the analysis, and a total of 308 disclosure checklists are carefully identified and validated to arrive at the compliance index. For the compliance index computation, a disclosed item is marked " 1 " and " 0 " for an undisclosed but applicable item. For non-applicable items, the value of "NA" is assigned (Tsalavoutas and Evans, 2010).

\subsection{Independent Variables}

In line with the theoretical and empirical literature review, the study identifies six (6) firm-specific characteristics and establishes hypotheses. The selected variables are company size, profitability, leverage, auditor type, company age, and industry type.

Table 3.1 Description of Independent Variables

\begin{tabular}{ll}
\hline Variable & \multicolumn{1}{c}{ Proxy/Measurement } \\
\hline Company Size & Natural log of total asset \\
Profitability & Return of Asset (Earnings before tax and interest/capital employed) \\
Leverage & The ratio of total debt to book value of total assets \\
Auditor Type & Dummy value (1 for firms audited by Big 4, 0 for otherwise) \\
Company Age & Number of years that the firm has been in existence since the establishment \\
Financial & Dummy value (1 for listed banks/insurance/investment company, 0 for otherwise) \\
Manufacturing & Dummy value (1 for listed manufacturing and trading company, 0 for otherwise). \\
Agric-Processing & Dummy value (1 for listed agric processing, forestry company, 0 for otherwise) \\
Mining/Oil & Dummy value (1 for listed mining or oil company, 0 for otherwise) \\
Pharmaceutical/Beverage & Dummy value (1 for pharmaceutical or beverage company, 0 for otherwise) \\
Paper/IT/Service & Dummy value (1 for paper conversion, IT and service company, 0 for otherwise) \\
\hline
\end{tabular}

Source: Authors construct.

\subsection{Model Development}

This study uses longitudinal panel data to establish a relationship between the level of compliance and the predictive variables. The study conducts a multiple regression analysis to estimate the degree to which the selected corporate attributes (company size, profitability, leverage, auditor type, company age, and industry type) influence the level of mandatory IFRS disclosure requirement. The multivariate linear regression model is constructed and estimated for the two approaches as:

$$
\begin{aligned}
& T C I D A_{x}=\beta_{0}+\beta 1 C S I Z E_{i t}+\beta 2 R O A_{i t}+\beta 3 L E V_{i t}+\beta 4 C A G E_{i t}+\beta 5 A U D_{i t}+\beta 6 F I N_{i t}+\beta 7 M A N_{i t} \\
& +\beta 8 A G P R_{i t}+\beta 9 \text { MOIL }_{i t}+\beta 10 P B E V_{i t}+\beta 11 P I T S_{i t}+\varepsilon_{i t} \\
& \text { TCIPA }_{x}=\beta_{0}+\beta 1 \text { CSIZE }_{i t}+\beta 2 R O A_{i t}+\beta 3 L E V_{i t}+\beta 4 C A G E_{i t}+\beta 5 A U D_{i t}+\beta 6 F I N_{i t}+\beta 7 M A N_{i t} \\
& +\beta 8 A G P R_{i t}+\beta 9 \text { MOIL }_{i t}+\beta 10 P B E V_{i t}+\beta 11 P I T S_{i t}+\varepsilon_{i t}
\end{aligned}
$$

Where:

TCIDA is the total compliance index dichotomous approach for company (x), TCIPA is the total compliance index partial approach for company $(\mathrm{x}), \mathrm{CSIZE}=$ company size, LEV = leverage, $\mathrm{ROA}=$ profitability, $\mathrm{CAGE}=$ company age, AUD = auditor type, FIN = financial industry, MAN = manufacturing industry, AGPR = agro processing industry, MOIL = mining/oil industry, PBEV $=$ pharmaceutical/beverage industry, PITS $=$ paper conversion and IT/service industry, $\beta 0=$ constant term, $\beta 1$ to $\beta 11=$ coefficient of the independent variables, and $\varepsilon i t=$ residual term

\section{Results}

\subsection{Descriptive Statistics}

Table 2 reports the descriptive statistics for the dependent and explanatory variables in this study. The descriptive statistics show the mean, maximum, minimum, and standard deviation. The presentation of the descriptive analysis covers results relating to both compliance indices. Table 2 shows the overall mean score of $86.4 \%$ (TCIDA) and $85.8 \%$ (TCIPA). The findings of this work run consistent with prior studies (Tsalavoutas and Evans, 2010; Abdullah and Minhat, 2013), where compliance is higher for the dichotomous approach. And this argument in IFRS literature receives support from Street and Gray (2002). Under the dichotomous method for the dependent variable, the maximum, minimum, and standard deviation are $99 \%, 61 \%$, and $7 \%$, respectively. The TCIPA also shows a maximum score of $98.2 \%$, a minimum score of $64.3 \%$, and $8 \%$ standard deviation values. The results establish that full compliance is generally a mirage and not under any sector or company on the exchange over the ten years since IFRS adoption. 
Table 4.1 Descriptive statistics

\begin{tabular}{|c|c|c|c|c|c|c|c|c|c|c|c|c|c|c|}
\hline & \multicolumn{2}{|c|}{ Overall } & \multicolumn{2}{|c|}{ Fin } & \multicolumn{2}{|c|}{ Man } & \multicolumn{2}{|c|}{ AGPR } & \multicolumn{2}{|c|}{ MOIL } & \multicolumn{2}{|c|}{ PBEV } & \multicolumn{2}{|c|}{ PITS } \\
\hline & A & B & A & $\mathrm{B}$ & A & B & A & B & $\mathrm{A}$ & B & A & B & $\mathrm{A}$ & B \\
\hline Mean & 0.864 & 0.858 & 0.903 & 0.889 & 0.861 & 0.866 & 0.792 & 0.759 & 0.894 & 0.892 & 0.86 & 0.883 & 0.791 & 0.782 \\
\hline Maximum & 0.99 & 0.982 & 0.988 & 0.981 & 0.924 & 0.96 & 0.98 & 0.933 & 0.99 & 0.982 & 0.938 & 0.944 & 0.944 & 0.932 \\
\hline Minimum & 0.61 & 0.643 & 0.8 & 0.745 & 0.772 & 0.738 & 0.672 & 0.65 & 0.722 & 0.743 & 0.726 & 0.72 & 0.61 & 0.643 \\
\hline St. Dev. & 0.074 & 0.08 & 0.04 & 0.05 & 0.04 & 0.05 & 0.07 & 0.08 & 0.1 & 0.08 & 0.05 & 0.07 & 0.08 & 0.09 \\
\hline Firms & & & & & & & & & & & & & & \\
\hline
\end{tabular}

Paired-test $2.2403^{* *}$

NB: where A is TCIDA and B is TCIPA

Source: Stata results

For the industries, the highest compliance means score in descending order under the TCIDA from FIN (90.3\%), MOIL (89.4\%), MAN (86.1\%), PBEV (86\%), AGPR (79.2\%), and PITS (79.1\%). Under the TCIPA the ranking is in order of MOIL (89.2\%), FIN (88.9\%), PBEV (88.3\%), MAN (86.6\%), PITS (78.2\%) and AGPR (75.9\%). Table 2 shows a completely different ranking of compliance score under both measures. This result brings to bear the differences in compliance under the sectors and how the method of computing compliance influences the variation in ranking of the industries score. The evidence of the standard deviation under both approaches shows a close variation concerning mandatory compliance. Table 2 reports the results of both paired sample t-test which are significant at 5\% level, confirming that the aggregate compliance scores under the two methods are significantly different.

\subsection{ANOVA Results}

Concerning the industry, the study hypothesizes that there might be significant differences among the various sectors. The level of compliance varies among the sectors, as shown in Table 3. Consequently, the researcher performs the ANOVA test. Concerning hypothesis 6, the study explores differences among the industries about compliance rates by running the test. The study has the companies categorized under six industries. The industry effects are significant. Table 3 depicts the difference among the industries $(\mathrm{F}=27.85, \mathrm{p}<0.01)$. The Post-Hoc comparison is employed by using the Turkey HSD test. The outcome suggests how the industries differ when subjected to pairing. For instant statistically significant difference exist between the level of compliance of FIN $(\mathrm{TCIDA}=90.3 \%, \mathrm{SD}=0.038)$ and MAN (TCIDA $=86.1 \%, \mathrm{SD}=0.039$ ), AGPR (TCIDA=79.2\%, SD=0.070), PBEV (TCIDA $=86 \%, S D=0.054$ ) and PITS (TCIDA=79.1\%, SD=0.08). The findings mean that there is statistical significance between the compliance with IFRS disclosure requirement of the FIN than the MAN, AGPR, PBEV and PITS. Other differences are also established between industries under TCIPA in table 3 where the mean difference shows statistical significance.

Table 4.2 Industry Anova

\begin{tabular}{|l|l|l|l|l|c|c|}
\hline & \multicolumn{3}{|c|}{ TCIDA } & \multicolumn{3}{c|}{ TCIPA } \\
\hline $\begin{array}{l}\text { Industry } \\
\text { Type (a) }\end{array}$ & $\begin{array}{l}\text { Industry } \\
\text { Type (b) }\end{array}$ & $\begin{array}{l}\text { Mean difference } \\
(\mathrm{a}-\mathrm{b})\end{array}$ & Std. error & $\begin{array}{l}\text { Industry } \\
\text { Type (b) }\end{array}$ & $\begin{array}{l}\text { Mean difference } \\
\text { (a-b) }\end{array}$ & Std. error \\
\hline FIN & MAN & $0.043^{* *}$ & 0.01 & MANU & 0.023 & 0.011 \\
\hline & AGPR & $0.112^{* *}$ & 0.014 & AGR & $0.130^{* *}$ & 0.016 \\
\hline & MOIL & 0.01 & 0.012 & MOIL & -0.003 & 0.013 \\
\hline & PBEV & $0.043^{* *}$ & 0.013 & PBEV & 0.006 & 0.014 \\
\hline & PITS & $0.113^{* *}$ & 0.011 & PCITS & $0.107^{* *}$ & 0.012 \\
\hline MAN & FIN & $-0.043^{* *}$ & 0.010 & FIN & -0.023 & 0.011 \\
\hline & AGPR & $0.069^{* *}$ & 0.015 & AGR & $0.107 * *$ & 0.017 \\
\hline & MOIL & $-0.033^{* *}$ & 0.013 & MOIL & -0.026 & 0.014 \\
\hline & PBEV & 0 & 0.014 & PBEV & -0.017 & 0.015 \\
\hline & PITS & $0.070^{* *}$ & 0.012 & PCITS & $0.084^{* *}$ & 0.014 \\
\hline AGPR & FIN & $-0.112^{* *}$ & 0.014 & FIN & $-0.130^{* *}$ & 0.016 \\
\hline & MAN & $-0.069^{* *}$ & 0.015 & MANU & $-0.107 * *$ & 0.017 \\
\hline & MOIL & $-0.102^{* *}$ & 0.016 & MOIL & $-0.133^{* *}$ & 0.018 \\
\hline & PBEV & $-0.068^{* *}$ & 0.017 & PBEV & $-0.124 * *$ & 0.019 \\
\hline & PITS & 0.001 & 0.016 & PCITS & -0.022 & 0.018 \\
\hline
\end{tabular}




\begin{tabular}{|l|l|l|l|l|c|c|}
\hline & \multicolumn{3}{|c|}{ TCIDA } & \multicolumn{3}{c|}{ TCIPA } \\
\hline $\begin{array}{l}\text { Industry } \\
\text { Type (a) }\end{array}$ & $\begin{array}{l}\text { Industry } \\
\text { Type (b) }\end{array}$ & $\begin{array}{l}\text { Mean difference } \\
(\mathrm{a}-\mathrm{b})\end{array}$ & Std. error & $\begin{array}{l}\text { Industry } \\
\text { Type (b) }\end{array}$ & $\begin{array}{l}\text { Mean difference } \\
(\mathrm{a}-\mathrm{b})\end{array}$ & Std. error \\
\hline MOIL & FIN & -0.01 & 0.012 & FIN & 0.003 & 0.013 \\
\hline & MAN & $0.033^{*}$ & 0.013 & MANU & 0.026 & 0.014 \\
\hline & AGPR & $0.102^{* *}$ & 0.016 & AGR & $0.133^{* *}$ & 0.018 \\
\hline & PBEV & 0.034 & 0.015 & PBEV & 0.009 & 0.016 \\
\hline & PITS & $0.103^{* *}$ & 0.014 & PCITS & $0.110^{* *}$ & 0.015 \\
\hline PBEV & FIN & $-0.043^{* *}$ & 0.013 & FIN & -0.006 & 0.014 \\
\hline & MAN & 0 & 0.014 & MANU & 0.017 & 0.015 \\
\hline & AGPR & $0.068^{* *}$ & 0.017 & AGR & $0.124^{* *}$ & 0.019 \\
\hline & MOIL & -0.034 & 0.015 & MOIL & -0.009 & 0.016 \\
\hline & PITS & $0.070^{* *}$ & 0.015 & PCITS & $0.102^{* *}$ & 0.016 \\
\hline PITS & FIN & $-0.113^{* *}$ & 0.011 & FIN & $-0.107^{* *}$ & 0.012 \\
\hline & MAN & $-0.070^{* *}$ & 0.012 & MANU & $-0.084^{* *}$ & 0.014 \\
\hline & AGPR & -0.001 & 0.016 & AGR & 0.022 & 0.018 \\
\hline & MOIL & $-0.103^{* *}$ & 0.014 & MOIL & $-0.110^{* *}$ & 0.015 \\
\hline & PBEV & $-0.070^{* *}$ & 0.015 & PBEV & $-0.102^{* *}$ & 0.016 \\
\hline
\end{tabular}

Note: $* \mathrm{p}<0.10$, two-tailed; $* * \mathrm{p}<0.05$, two-tailed

Source: Stata Results (2021)

Table 4 exhibits details of the statistical description of the predictive value. Table 4 reports a mean return on asset at 3.4\% for the Ghanaian listed firms for the ten years with a maximum and minimum value of $28.3 \%$ and $64.9 \%$, respectively. The result further reveals that the company size measured as the log of total assets ranged between 4.963 to 10.11 with the mean value of 8.156 . The natural $\log$ is adopted to mitigate the associated skewness using a nominal value consistent with several studies (Al-Shammari, 2005; 2011; Appiah et al., 2016). The table shows a statistics description value ranging from $2.2 \%$ to $346 \%$, with an average of $70.7 \%$. The outcome indicates that for every GHC10, GHC7 of the external debts of the listed firms in Ghana are from external sources. Again on the type of audit firm chosen for the firm's audit, close to $77.4 \%$ of the firm's financial statements were audited by one of the Big 4, which means that $22.6 \%$ of the financial statements receive local auditing firm arrangement. The firm age is measured as the years in existence post-incorporation and the study shows a mean of 37.85 years for the Ghanaian listed firms.

Table 4.3 Descriptive Statistics of the Explanatory Variables

\begin{tabular}{lcccc}
\hline Variable & Mean & Max & Min & Std. Dev. \\
\hline CSIZE & 8.156 & 10.11 & 4.963 & 1.137 \\
ROA & 0.034 & 2.827 & -0.649 & 0.217 \\
LEV & 0.707 & 3.459 & 0.022 & 0.396 \\
AUD & 0.774 & 1 & 0 & 0.419 \\
CAGE & 37.85 & 93 & 1 & 18.61 \\
FIN & 0.344 & 1 & 0 & 0.476 \\
MAN & 0.201 & 1 & 0 & 0.402 \\
AGPR & 0.076 & 1 & 0 & 0.266 \\
MOIL & 0.132 & 1 & 0 & 0.339 \\
PBEV & 0.101 & 1 & 0 & 0.301 \\
PITS & 0.146 & 1 & 0 & 0.354 \\
\hline SOurce: Stata & & &
\end{tabular}

Source: Stata results

\subsection{Univariate Analysis}

To meet the regression assumption, an association between the variables is conducted to identify the presence of multicollinearity. The Pearson product-moment correlation approach is adopted for this study to render that test. The correlation matrix shows the relationship between the compliance index (dependent variable) - under both methods and the explanatory variables as well as the correlation among the latter variables. Table 5 displays the Pearson correlation matrix. There is a significant correlation between the dependent variable (under both methods) and all the other non-industrial independent variables at a 5\% significance level except for firm age. 
The leverage and ROA shows no significant relation between the TCIPA. According to Cooper and Schindler (2009), the critical threshold for multicollinearity is to have a correlation value of less than $80 \%$. The table reveals the highest correlation value among the independent variables at $r=0.544$ which existed between the firm's size and the financial industry and between the dependent variables (under both methods) and the size of the firm, a positive association at $r=0.656$ (TCIPA) and $r=0.669$ (TCIDA). The relationship between the disclosure indices and firm size under both methods are below the rule of thumb yet raises concern for further testing for multicollinearity.

\begin{tabular}{|l|c|c|c|c|c|c|c|c|c|c|c|}
\hline & CSIZE & LEV & ROA & AUD & CAGE & FIN & MAN & AGPR & MOIL & PBEV & PITS \\
\hline & & & & & & & & & & & \\
\hline & & & & & & & & & & & \\
\hline CSIZE & 1 & & & & & & & & & & \\
\hline LEV & -0.089 & 1 & & & & & & & & & \\
\hline ROA & 0.063 & $-0.192^{* *}$ & 1 & & & & & & & & \\
\hline AUD & $0.471^{* *}$ & $-0.230^{* *}$ & 0.089 & 1 & & & & & & & \\
\hline CAGE & -0.072 & $-0.293^{* *}$ & $0.126^{* *}$ & $0.231^{* *}$ & 1 & & & & & & \\
\hline FIN & $0.544^{* *}$ & 0.073 & 0.037 & $0.233^{* *}$ & 0.022 & 1 & & & & & \\
\hline MAN & $-0.179^{* *}$ & -0.052 & 0.055 & 0.002 & $0.193^{* *}$ & $-0.363^{* *}$ & 1 & & & & \\
\hline AGPR & $-0.226^{* *}$ & $0.097^{*}$ & -0.068 & $-0.157^{* *}$ & $-0.124^{* *}$ & $-0.208^{* *}$ & $-0.144^{* *}$ & 1 & & & \\
\hline MOIL & $0.336^{* *}$ & -0.045 & -0.005 & 0.014 & $-0.169^{* *}$ & $-0.282^{* *}$ & $-0.196^{* *}$ & $-0.112^{*}$ & & 1 & \\
\hline PBEV & $-0.197^{* *}$ & $-0.254^{* *}$ & 0.012 & $0.098^{*}$ & $0.165^{* *}$ & $-0.242^{* *}$ & $-0.168^{* *}$ & -0.096 & $-0.131^{* *}$ & 1 & \\
\hline PITS & $-0.513^{* *}$ & $0.151^{* *}$ & -0.067 & $-0.295^{* *}$ & $-0.135^{* *}$ & $-0.299^{* *}$ & $-0.207^{* *}$ & $-0.118^{* *}$ & $-0.161^{* *}$ & $-0.138^{* *}$ & 1 \\
\hline TCIPA & $0.656^{* *}$ & -0.109 & -0.062 & $0.502^{* *}$ & 0.069 & $0.273^{* *}$ & 0.045 & $-0.354^{* *}$ & $0.161^{* *}$ & $0.102^{*}$ & $-0.394^{* *}$ \\
\hline TCIDA & $0.669^{* *}$ & $-0.014^{* *}$ & $-0.119^{* *}$ & $0.435^{* *}$ & 0.021 & $0.387^{* *}$ & -0.026 & $-0.284^{* *}$ & $0.157^{* *}$ & -0.018 & $-0.413^{* *}$ \\
\hline
\end{tabular}

Table 4.4 Pearson Product Moment Correlation of the Dependent and the Explanatory Variables

Note: * Correlation is significant at the 0.10 level two-tailed)

** Correlation is significant at the 0.05 level two-tailed

Source: Stata Results (2021)

\subsection{Multiple Regresssion}

To address the second objective, which is to establish the association between the disclosure compliance index and the explanatory variables; the hypothesis is tested through the performance of the regression analysis. Before the regression outcome, a panel unit root test is conducted to establish the stationarity of the data. The fisher-type approach is used due to the unbalanced nature of the data. The outcome of the unit root testing, doesn't show any spurious data. The regression result is presented under the two compliance indices. Under TCIDA, it shows an Fstats of $32.38(\mathrm{p}=0.000)$ and F-stats of $40.46(\mathrm{p}=0.000)$ under the TCIPA, both of which indicate that the results support the significance of the regression model. The regression results show an $\mathrm{R}^{2}$ of 0.539 and 0.594 under both TCIDA and TCIPA, respectively. This outcome tells how the model's predictive variables explain 53.9\% and $59.4 \%$ of the variation in the disclosure index. In the test for multicollinearity, the study reveals VIF test results where multicollinearity is identified for the mining and oil industry and is excluded in the regression analysis. Table 6 displays the largest is VIF value of 3.36 which is within range. Earlier studies such as Mendenhall and Sincich (1989) and Neter et al., (1983) benchmarked VIF below 10 as a sign of nonmulticollinearity. In aligning all the needed tests, the model developed is statistically significant to explain the quality of financial reporting. 
Table 4.5 Regression Analysis

\begin{tabular}{|c|c|c|c|c|c|c|c|c|c|}
\hline & \multicolumn{4}{|c|}{ TCIDA } & \multicolumn{4}{|c|}{ TCIPA } & \multirow[t]{2}{*}{ VIF } \\
\hline & Coefficient & Std. err. & t-value & $\begin{array}{l}\text { p- } \\
\text { value }\end{array}$ & Coefficient & Std. err. & t-value & p-value & \\
\hline CSIZE & $0.036^{* *}$ & 0.005 & 7.35 & 0.000 & $0.048 * *$ & 0.005 & 9.62 & 0.000 & 3.41 \\
\hline LEV & -0.013 & 0.008 & -1.52 & 0.129 & 0.011 & 0.009 & 1.25 & 0.213 & 1.24 \\
\hline ROA & $-0.067 * *$ & 0.014 & -4.69 & 0.000 & $-0.049 * *$ & 0.015 & -3.35 & 0.001 & 1.05 \\
\hline AUD & $0.021^{* *}$ & 0.009 & 2.33 & 0.021 & $0.033 * *$ & 0.009 & 3.66 & 0.000 & 1.53 \\
\hline CAGE & 0.001 & 0.001 & -0.44 & 0.658 & 0.001 & 0.001 & 0.47 & 0.642 & 1.29 \\
\hline FIN & 0.014 & 0.010 & 1.45 & 0.149 & -0.002 & 0.010 & -0.19 & 0.851 & 2.48 \\
\hline MAN & 0.020 & 0.013 & 1.55 & 0.121 & $0.041 * *$ & 0.013 & 3.19 & 0.002 & 2.82 \\
\hline AGPR & $-0.031^{*}$ & 0.016 & -1.93 & 0.054 & $-0.039 * *$ & 0.017 & -2.33 & 0.020 & 2.01 \\
\hline PBEV & 0.022 & 0.015 & 1.45 & 0.149 & $0.069 * *$ & 0.016 & 4.4 & 0.000 & 2.33 \\
\hline PITS & -0.011 & 0.016 & -0.68 & 0.495 & 0.012 & 0.016 & 0.74 & 0.461 & 3.36 \\
\hline cons & 0.563 & 0.045 & 12.45 & 0.000 & 0.415 & 0.047 & 8.9 & 0.000 & - \\
\hline$\overline{\mathrm{F}}$ statistics & 32.38 & & & & 40.46 & & & & \\
\hline Prob & 0.000 & & & & 0.000 & & & & \\
\hline R Squared & 0.539 & & & & 0.5936 & & & & \\
\hline Adj R Squared & 0.522 & & & & 0.5789 & & & & \\
\hline Observation & 288 & & & & 288 & & & & \\
\hline
\end{tabular}

Note: $* \mathrm{p}<0.10$, two-tailed; $* * \mathrm{p}<0.05$, two-tailed

Source: Stata Results (2021)

\section{Hypothesis Testing Results}

The results of the hypothesis testing as follows:

\subsubsection{Company Size and Regression Results}

The hypothesis proposes that company size increases as compliance increases. In line with the agency theory argument, larger firms have a reputation to keep and a market standing to uphold. As indicated, Table 6 shows a positive association between the level of compliance and the company under both TCIDA and TCIPA. This results shows consistency with several other studies, such as Hossain and Hammami (2009) and Al-Shammari and Al-Sultan (2010). Based on the outcome, we can reject the null hypothesis.

\subsubsection{Profitability and Regression Results}

In the exploration, the prediction is for profitability to have a significant positive relationship with the level of compliance. The hypothesis is not supported under both approaches since it reports a negative association $(\beta=-$ 0.067, TCIDA) and ( $\beta=-0.049$, TCIPA) and they are significant under both indices at $p<0.05$. The possible reason can be that more profitable firms are unwilling to consent to ensure the quality of financial statement disclosure. In the same studies in Ghana, Appiah et al. (2016), Appiah Kubi and Rjoub (2017) and Yiadom and Atsunyo (2014), using the same measure (return on asset), all reported a negative relationship with the level of compliance. In line with the signal theory, a profitable firm discloses more information to assure shareholders of pursuing their agenda. The reports show that disclosure quality has no relation with profitability. This study confirms earlier studies (Juhmani, 2012; Alsaeed, 2006).

\subsubsection{Leverage and Regression Results}

In the initial prediction, leverage is estimated to show a significant positive relationship between the level of compliance. There is variation in outcomes under the two compliance indices. The research results found no significant association recorded but a positive association $(\beta=0.11$, TCIPA) and a negative association $(\beta=-0.013$, TCIDA). The agency theory assumes that highly leveraged firms must make available sufficient disclosure to give an impression of better performance. The positive relationship is consistent with studies like Ali et al. (2004), Jaggi and Low (2000) and not Demir and Bahadir (2014).

\subsubsection{Auditor Type and Regression results}

The general proposition is that firms audited by the BIG 4 accountancy firms are likely to disclose more accounting information or have a higher level of compliance. The study outcome shows a significant positive relationship between the level of compliance and the auditing firm responsible for the audit. Table 6 reports a result consistent with the hypothesis which applies to both TCIDA and TCIPA and other previous works (Appiah et al., 2016; Glaum and Street, 2003).

\subsubsection{Company Age and Regression Results}

The research assumes that older firms are more compliant because they are well established and have systems instituted to allow for sufficient disclosure. The study hypothesizes that there is a significant positive association between the level of compliance and company age. This study shows a positive relationship between company age and the level of compliance as initially hypothesized but found no statistical significance. The method of 
measuring compliance does not cause any mixed outcome. Studies like Juhmani (2012) and Alsaeed (2006) have no common grounds with the hypothesis.

\subsection{Robustness testing}

To test the sensitivity of the results against modification in the data, a robustness test is conducted. To examine the test, a different measure of profitability is used. The initial measure of profitability in the original model is the return on assets (ROA) which is replaced by return on equity (ROE) as Table 7 reports. There is a minor departure in the robustness results, however, it can be said that the robustness regression results are substantially consistent with the outcome of the original model under both the TCIDA and TCIPA models.

Table 4.6 Robustness Test Results

\begin{tabular}{|c|c|c|c|c|c|c|c|c|}
\hline & \multicolumn{4}{|c|}{ TCIDA } & \multicolumn{4}{|c|}{ TCIPA } \\
\hline & Coefficient & Std. err. & $\mathrm{t}$ & p-value & Coefficient & Std. err. & $\mathrm{t}$ & p-value \\
\hline CSIZE & $0.035 * *$ & 0.005 & 6.74 & 0.000 & $0.047 * *$ & 0.005 & 9.01 & 0.000 \\
\hline LEV & -0.007 & 0.009 & -0.79 & 0.428 & $0.015^{*}$ & 0.009 & 1.73 & 0.084 \\
\hline ROE & -0.008 & 0.006 & -1.33 & 0.186 & $-0.012 * *$ & 0.006 & -2.05 & 0.041 \\
\hline AUD & $0.021 * *$ & 0.009 & 2.25 & 0.025 & $0.034 * *$ & 0.009 & 3.67 & 0.000 \\
\hline CAGE & 0.001 & 0.001 & -0.68 & 0.499 & 0.001 & 0.001 & 0.3 & 0.767 \\
\hline FIN & 0.014 & 0.010 & 1.35 & 0.177 & -0.002 & 0.010 & -0.18 & 0.857 \\
\hline MAN & 0.017 & 0.013 & 1.31 & 0.190 & $0.039 * *$ & 0.013 & 2.94 & 0.004 \\
\hline AGPR & $-0.034 * *$ & 0.017 & -2.01 & 0.045 & $-0.045^{* *}$ & 0.017 & -2.62 & 0.009 \\
\hline PBEV & 0.021 & 0.016 & 1.31 & 0.190 & $0.066^{* *}$ & 0.016 & 4.13 & 0.000 \\
\hline PITS & -0.013 & 0.016 & -0.78 & 0.434 & 0.008 & 0.016 & 0.5 & 0.614 \\
\hline cons & 0.571 & 0.047 & 12.03 & 0.000 & 0.430 & 0.048 & 8.98 & 0.000 \\
\hline$\overline{\text { F statistics }}$ & 28.31 & & & & 38.8 & & & \\
\hline Prob & 0.000 & & & & 0.000 & & & \\
\hline R Squared & 0.505 & & & & 0.583 & & & \\
\hline Adj R Squared & 0.487 & & & & 0.568 & & & \\
\hline Observation & 288 & & & & 288 & & & \\
\hline
\end{tabular}

Note: $* \mathrm{p}<0.10$, two-tailed; $* * \mathrm{p}<0.05$, two-tailed

Source: Stata Results (2021)

\section{Conclusion and Recommendation}

IFRS is a remarkable height in the history of accounting which has helped facilitate a better understanding of financial reporting by investors worldwide due to the uniformity in the presentation and preparation of financial reports and the openness it gives to those who want to raise capital. Ghana wholly adopted IFRS as a progressive project that aims to enhance the quality of financial reporting. A handful of attempts to examine the depth of accounting information disclosure and those corporate attributes that influence disclosure compliance with IFRS by Ghanaian listed firms have been conducted.

This study investigates the degree to which the listed firms complied with the IFRS disclosure requirement since a decade of adoption. This study used the unweighted method of measuring compliance and adopted both the dichotomous and partial approaches. The discovery shows an overall mean compliance score of $86.4 \%$ (TCIDA) and $85.8 \%$ (TCIPA). The outcome of the findings confirms prior studies of Tsalavoutas et al. (2010) and Abdullah and Minhat (2013), where comparatively, the compliance scores favored the dichotomous method. For a decade, full compliance with IFRS remains a mirage as some firms provide mandatory information, which is far insufficient, for instance, 61\% (dichotomous method) and 64.3 (partial compliance method). The lax enforcement for breaching the law concerning non-compliance is the attribute for significant non-compliance. The absence of punitive measures deterring enough paves the way for the treatment of mandatory disclosure like voluntary disclosure.

For the industry effect on compliance, the study discovers a variation in compliance. The TCIDA of the industries in the descending order shows the highest score for the FIN as $90.3 \%$, followed by MOIL $89.4 \%$. The MAN reports a mean score of $86.1 \%$, PBEV $86 \%$, AGPR $79.2 \%$, and PITS $79.1 \%$. However, the ranking order is different under the TCIPA as MOIL recorded the highest score at $89.2 \%$, and the next is FIN at $88.9 \%$. The PBEV recorded $88.3 \%$, MAN $86.6 \%$, PITS $78.2 \%$ and AGPR $75.9 \%$. Given the facts, both methods provide a more informative outcome. It can be argued that the generalization in the ranking of the compliance score of the industries is limited to the method chosen since both methods have variations in ranking.

The study employed corporate attributes, namely company size, profitability, leverage, auditor type, company age, and industry type. The variables were regressed to explain the variation in the level of compliance with the IFRS mandatory disclosure requirement. The company size and auditor type are consistent with the 
hypothesis, which proposed a significant positive association between them and the level of compliance. Profitability, measured as return on asset, showed a significant negative association under both compliance measures. There is no statistical significance achieved for leverage and company age.

The study has a clear contribution it renders to literature. The ramification of this study is essential to the literature on IFRS, accounting practice and regulation in Ghana. The study outcome is solid since the findings are grounded in extensive firm years coverage and dataset. The results bring to bear the industries which need attention in terms of their level of compliance and the role of auditors to promote complete compliance with IFRS. The findings are also beneficial to other countries in Africa and non-African developing countries yet to adopt IFRS and those who already practice IFRS. This study guides regulators to ensure that in the subsequent year's compliance at least does not fall below what is recorded instead of providing a progressive trajectory moving forward. The full benefit of IFRS must be worked on by the relevant authorities to actualize it. Lastly, other users like investors may know firms' level of disclosure, which may help them ask questions and demand more from such companies.

On the other side of the discussion are the limitations of the study. A handful of corporate variables are used makes it misleading to generalize the outcome beyond what it presents. In the future, unquoted firms can become the critical area of study. Though they are not required to disclose accounting information using IFRS, such a study may discuss unquoted firms. With the limitation on firm-specific characteristics, the subsequent study can look at other determinants like corporate governance mechanism and other corporate attributes like internationalization; multiple listing can influence compliance. Several empirical studies have exposed us to the dynamism of mandatory disclosure. Still, the pursuit of the suggested future study will enhance the holistic understanding of compulsory disclosure studies in Ghana.

\section{References}

Abdullah, M., Minhat, M. (2013). Corporate disclosure quality in Malaysia. International Journal of Education and Research, 1(7), 1-14

Abdullah, M., Sulaiman, N. A., Ismail, K., Sapei, N. S. (2012). Compliance with International Financial Reporting Standards (IFRSs) in a developing country: Evidence from Malaysia. Asian Journal of Accounting Perspective, 5(1): 23-34.

Agyei-Mensah, B.K. (2014). Adoption of International Financial Reporting Standards (IFRS) in Ghana and the quality of financial statement disclosures. International Journal of Accounting and Financial Reporting, 3(2), 269-282.

Ahmed, K., Nicholls, D. (1994) The impact of non-financial company characteristics on mandatory disclosure compliance in developing countries: The Case of Bangladesh, International Journal of Accounting, 29: 6277.

Al-Shammari, B. A. (2005). Compliance with International Accounting Standards by listed companies in the Gulf Co-operation Council member states: An empirical study. Unpublished PhD work. 1- 217.

Al-Shammari, B. (2008). Corporate governance and voluntary disclosure in Kuwait. Review of Business Research, 8(1): 62-81

Al-Shammari, B. (2011). Factors influencing the extent of mandatory compliance with International Financial Reporting Standards: The case of Kuwaiti listed companies. Journal of International Business and Economics, 11(4): 11-31.

Al-Shammari, B., Al-Sultan, W. (2010). Corporate governance and voluntary disclosure in Kuwait. International Journal of Disclosure and Governance, 7(3): 262-280.

Al-Shammari, B., Brown, P., Tarca, A. (2008). An investigation of compliance with International Accounting Standards by listed companies in the Gulf Co-Operation Council member states. The International Journal of Accounting, 43(4): 425-447.

Al-Shiab, M. (2003). Financial consequences of IAS adoption: The case of Jordan (Doctoral dissertation, Newcastle University).

Ali, M. J., Ahmed, K., Henry, D. (2004). Disclosure compliance with national accounting standards by listed companies in South Asia. Accounting and Business Research, 34(3): 183-199.

Alsaeed, K. (2006). The association between firm-specific characteristics and disclosure: The case of Saudi Arabia. Managerial Auditing Journal, 21(5): 476-496.

Appiah, O. K., Awunyo-Vitor, D., Mireku, K., Ahiagbah, C. (2016). Compliance with International Financial Reporting Standards: The case of listed firms in Ghana. Journal of Financial Reporting and Accounting, 14(1): $131-156$.

Appiah-Kubi, S. N., Rjoub, H. (2017). Adoption and compliance with IFRS by listed firms in Ghana and the extent of financial statement disclosures. Computational Methods in Social Sciences. 10-25.

Ashbaugh, H., Pincus, M. (2001). Domestic accounting standards, International Accounting Standards, and the predictability of earnings. Journal of Accounting Research, 39(3): 417-434. 
Assenso-Okofo, O., Ali, M. J., Ahmed, K. (2009). The development of accounting and reporting in Ghana. The International Journal of Accounting, 46(4): 459-480.

Al-Mutawaa, A., Hewaidy, A. M. (2010). Disclosure level and compliance with IFRS: An empirical investigation of Kuwaiti companies. International Business and Economics Research, 9(5): 33-50.

Brown, P. (2011). International Financial Reporting Standards: What are the benefits? Accounting and Business Research, 41(3): 269-285.

Cairns, D. (1997). International Federation of Accountants: 20 years on. World Accounting Report (October).

Chatham, M. D. (2008). Assessing the extent of compliance with international accounting standards. Journal of International Business Research, 7(1), 252-274.

Choi, F. D., Mueller, S. (1992). What is coefficient alpha? An examination of theory and application. Journal of Applied Psychology, 78(2): 98-104.

Companies Act (2019). https://rgd.gov.gh/docs/Act\%20992.pdf

Cooke, T. E. (1989). Voluntary corporate disclosure by Swedish companies. Journal of International Financial Management \& Accounting, 1(2): 171-195.

Cooper, D. R. Schindler, P. (2008). Business research methods. 10th Edition. Boston: McGraw-Hill Irwin

DeAngelo, L. E. (1981). Auditor size and audit quality. Journal of Accounting and Economics, 3(3): 183-199.

Demir, V., Bahadir, O. (2014). The extent of compliance with International Financial Reporting Standards (IFRS) by listed companies in Turkey. Accounting and Management Systems, 13(1): 4-34.

Elfeky, M. I., Nasiri, A. (2017). The determinants of voluntary disclosure in emerging markets: The case of Egypt. Journal of Poverty, Investment and Development, 36: 1-12.

Eng, L., Mak, Y. (2003). Corporate governance and voluntary disclosure. Journal of Accounting and Public Policy, 22(4): 325-345.

Fekete, S., Matis, D., Lukacs, J. (2008). Factors influencing the extent of corporate compliance with IFRS: The case of Hungarian listed companies.

Flynn, T. (2008). US warming to IFRS as it moves on from GAAP. Retrieved December 9, 2008 from http://www.ft.com/cms/s/0/ e944709e-7a19-11dd-bb93-000077b07658.html? nclick_check=1

Galani, D., Alexandridis, A., Stavropoulos, A. (2011). The association between the firm characteristics and corporate mandatory disclosure: The case of Greece. World Academy of Science, Engineering and Technology, 77: 101-107.

Ghana Stock Exchange (2009). Review of stock market performance. Available at http://www.gse.com.gh/

Glaum, M., Street, D. L. (2003). Compliance with the disclosure requirements of Germany's new market: IAS versus US GAAP. Journal of International Financial Management and Accounting, 14(1): 64-100

Hossain, M., Hammami, H. (2009). Voluntary disclosure in the annual reports of an emerging country: The case of Qatar. Advances in Accounting, Incorporating Advances in International Accounting, 25: 255-265.

Hossain, M., Perera, M. H., Rahman, A. R. (1995). Voluntary disclosure in the annual reports of New Zealand companies. Journal of International Financial Management and Accounting, 6(1): 69-87.

IAS Plus (2021). Overview of the structure of the IFRS foundation and IASB. Online. Available: https://www.iasplus.com/en/resources/ifrsf

Ibrahim, A. (2006). Corporate financial reporting reform in economies in transition: The extent of compliance with International Financial Reporting Standards disclosure requirements in annual reports. Ph.D. Thesis. Department of Accounting. University of Surrey Aleppo, Syria

Jaggi, B., Low, P. Y. (2000). Impact of culture, market forces, and legal system on financial disclosures. The International Journal of Accounting, 35(4): 495-519.

Jallad, Y. (2020.) The effects of board characteristics and ownership structure on compliance with mandatory IAS/IFRS disclosure requirements. Master's Thesis submitted to Qatar University, 1-147

Jensen, M., Meckling, W. (1976). Theory of the firm: Managerial behavior, agency costs and ownership structure. Journal of Financial Economics, 3(4): 305-360.

Juhmani, O. I. H. (2012). Factors influencing the extent of corporate compliance with IFRS: Evidence from companies listed on Bahrain Stock Exchange. Journal of International Business and Economics, 12(2): 67 79.

Mendenhall, W., Sincich, T. (1989). A second course in business: Regression analysis. Riverside, New Jersey, Bellen Publishing Company.

Neter, J., Wasserman, W., Kutner, M. H. (1983). Applied linear regression models, Homewood, IL: Richard D. Irwin.

Owusu-Ansah, S. (1998). The impact of corporate attributes on the extent of mandatory disclosure and reporting by listed companies in Zimbabwe. The International Journal of Accounting, 33(5): 605-631.

Owusu-Ansah, S., Yeoh, J. (2005). The effect of legislation on corporate disclosure practices. Abacus, 41(1): 92109.

Palmer, P. D. (2013). The impact of adopting IFRS in Australia: The extent and quality of disclosures and 
their relationship to corporate characteristics. School of Commerce Research Paper Series.

Patelli, L., Prencipe, A. (2007). The relationship between voluntary disclosure and independent directors in the presence of a dominant shareholder. European Accounting Review, 16(1): 5-33.

Patton, J., Zelenka, 1. (1997). An empirical analysis of the determinants of the extent of disclosure in annual reports of joint stock companies in the Czech Republic. The European Accounting Review, 6(4): 605-626.

Rajhi, M. (2014). International Financial Reporting Standards and level of compliance with mandatory disclosure requirements. International Journal of multidisciplinary Sciences and Engineering, 5(5): 1-6.

Samaha, K., Khlif, H. (2016). Adoption of compliance with IFRS in developing countries: A synthesis of theories and directions for future research. Journal of Accounting in Emerging Economies, 6(1): 33-49

Samaha, K., Dahawy, K., Hussainey, K., Stapleton, P. (2012). The extent of corporate governance disclosure and its determinants in a developing market: The case of Egypt. Advances in Accounting, 28, 168-178.

Street, D. L., Bryant, S. (2000). Disclosure level and compliance with IASs: A comparison of companies with and without US listings and fillings. International Journal of Accounting, 35(3): 305-329.

Street, D. L., Gray, S. J. (2001). Observance of International Accounting Standards: Factors explaining noncompliance by companies referring to the use of IAS. ACCA Research Monograph No. 74, London.

Street, D. L., Gray S. J. (2002). Factors influencing the extent of corporate compliance with International Accounting Standards: Summary of a research monograph. Journal of International Accounting, Auditing and Taxation, 11(1): 51-76.

Street, D., Gray, S., Bryant, S. (1999). Acceptance and observance of International Accounting Standards: An empirical study of companies claiming to comply with IAS. International Journal of Accounting, 34(1): $11-48$.

Tower, G., Hancock, P., Taplin, R. H. (1999). A regional study of listed companies' compliance with International Accounting Standards. Accounting Forum, 23(3): 293-305.

Tsalavoutas, I., Evans, L. (2010). Transition to IFRS in Greece: Financial statement effects and auditor size. Managerial Auditing Journal. 25(8): 814-842.

Tsalavoutas, I., Evans, L., Smith, M. (2010). Comparison of two methods for measuring compliance with IFRS mandatory disclosure requirements. Journal of Applied Accounting Research, 11 (3): 213-228.

Yiadom, E. M., Atsunyo, W. (2014). Compliance with International Financial Reporting Standards by listed companies in Ghana. International Journal of Business and Management, 9(10): 87-100.

ZakarI, M. A. (2014). Challenges of International Financial Reporting Standards (IFRS): Adoption in Libya. International Journal of Accounting and Financial Reporting, 4(2): 390-412

Zeff, S. A. (2012). The evolution of IASC into the IASB, and the challenges it faces. The Accounting Review, 87(3): 807-837. 